The University of San Francisco

USF Scholarship: a digital repository @ Gleeson Library |

Geschke Center

Public and Nonprofit Administration

School of Management

2007

\title{
Governance: The Collision of Politics and Cooperation
}

Richard Callahan

University of San Francisco, rfcallahan@usfca.edu

Follow this and additional works at: http://repository.usfca.edu/pna

Part of the Law and Politics Commons, and the Public Affairs, Public Policy and Public Administration Commons

\section{Recommended Citation}

Callahan, R. "Governance: The Collision of Politics and Cooperation”. Public Administration Review. 2007. (67). Pp. 299-301. DOI: $10.1111 / j .1540-6210.2007 .00714 . x$

This Article is brought to you for free and open access by the School of Management at USF Scholarship: a digital repository @ Gleeson Library | Geschke Center. It has been accepted for inclusion in Public and Nonprofit Administration by an authorized administrator of USF Scholarship: a digital repository@ Gleeson Library | Geschke Center. For more information, please contact repository@usfca.edu. 


\section{Case Study}

Richard Callahan is the associate dean and director of state capital and leadership programs at the University of Southern California, School of Policy, Planning, and Development. He directs the delivery of master's degree programs in Sacramento, as well as leadership and management development programs at the national, state, and county levels of government and for nonprofit health directors. His research interests include leadership in public and nonprofit organizations and governance. E-mail: rcallaha@usc.edu.

\section{Governance: The Collision of Politics and Cooperation}

Three newly established public agencies built regional rail projects in Los Angeles County from 1978 to 2002. The Los Angeles County Transportation Commission, the Los Angeles Metropolitan Transportation Authority, and the Alameda Corridor Transportation Authority were experiments in regional governance. Conventional understanding of these agencies only partially explains their successes and failures. One path to improved understanding is to combine research on the politics of designing new public agencies with research on cooperation in collective action problems. What emerges is an untold story of American politics: the evolution of mechanisms that promote cooperation. Four findings emerge: (1) conflict is inevitable; (2) public agencies can succeed despite the problems of politics; (3) successful regional solutions are intensely local; and (4) cooperation emerges from supplyside mechanisms that create new resources rather than reallocate existing resources. The limits of politics are neither random nor predestined - neither is the governance solution. emerges from what otherwise might appear to be a chaotic set of events described by former Los Angeles deputy mayor Ray Remy (1998) as "the failure of public administration in virtually every test." The cases of the regional transportation agencies invite inquiry into two ongoing controversies regarding institutions and organizations: improving the understanding of both "the life course of institutions" and the "relation between institutional and organizational processes" (Scott 1995, 146-47). In light of the emerging interest in researching governance (Hill and Lynn $2005,155)$ and with a view of governance as the study of "coordination and collaboration" (Heinrich, Hill, and Lynn 2004, 5), as well as the potential benefits of "cooperation and competition" (Feiock $2004,4)$, these cases examine governance as a product of institutional design that attempts to facilitate the benefits of coordination and collaboration in a political environment with intense competition among local governments for funding.
T The future of the Los Angeles region was sketched on a cocktail napkin in the lounge of the downtown New Otani hotel in 1978. Over dinner, staff from the newly formed Los Angeles County Transportation Commission drew rail corridors for a proposed ballot measure to increase the sales tax for 8 million residents countywide. In retrospect, the meeting initiated a twodecade departure from government to governance. The participants drew on a vision of governance in which regional cooperation would emerge out of a collision with competing political constituencies.

In a little over a decade, the promise of a regional rail system collapsed as interest group conflict overwhelmed the fragile cooperative mechanisms of governance. Upon careful examination, however, a pattern
The three newly established agencies that oversaw the regional projects were nothing less than experiments in governance, designed to overcome long-standing political conflicts. These agencies were building a transportation infrastructure for one of the world's largest and most demographically diverse metropolitan areas to carry it into the 21 st century. These three cases are the story of a search for resources totaling more than $\$ 12$ billion in local, state, federal, and private funding where previously there had been no money.

What emerges is an untold story of American politics: the evolution of mechanisms that promote cooperation among political entities and how these mechanisms succeed or fail. Four major findings 
emerge: (1) conflict is inevitable; (2) public agencies can overcome the interest group conflict that is inherent in politics; (3) successful regional solutions are intensely local; and (4) governance needs to address two parts of the political equation - the demand side and the supply side.

The regional transportation agencies, created between 1978 and 1992, responded to the predictable challenges of building regional projects in a politically fragmented region. The degree to which the cooperative mechanisms developed by each agency succeeded or failed helps explain what long-serving Los Angeles County supervisor Ed Edelman (2001) described as "Mayor Bradley putting together a consensus" and what the mayor's transportation board appointee Ray Remy (1998) characterized as the "meltdown of critical consensus." This invites the research question: Can governance emerge in a politically fragmented environment?

\section{The Limits of Current Understanding}

The conventional understanding of these projects suggests a wide range of causes for failure. Ineffective executive directors, fiscal officers who overestimated revenues, incompetent project managers, and overly influential contractors begin the list of explanations for their shortcomings. The impact of local politicians on selecting rail lines, succumbing to symbolic actions, and appointing alternates instead of serving themselves add to the litany of proposed shortcomings. The inevitability of cost overruns on federally funded new-start rail construction, the uncertainty of clearing federal and state environmental review processes, insufficient employment densities, and organizational fragmentation extend the list of potential explanations.

Making explicit the intrinsic problems of political design potentially addresses a contemporary critique of the field of public administration, that is, its perceived inattention to interesting questions of politics, institutions, and public organizations (March 1997; Moe 1994, 17; Wilson 1994). Research in public administration has inadequately advanced the study of complex institutional arrangements in American metropolitan regions (Ostrom 1998, 15). "If institutions matter, then which institutions are employed becomes a paramount concern. In particular, the selection, survival, adaptation, and evolution of institutional practices need to be understood" (Shepsle 1986, 52). In addition, there is a need to explain the how and why of institutional change in local government (Clingermayer and Feiock 2001, 6).

What remain a puzzle are the underlying causes of the conventional set of problems and an understanding of the features of successful cooperation. A more systematic, theory-driven study is needed to explain the design and evolution of governance in politically complex environments.

\section{Methodology: Case Study Analysis}

The cases were selected according to three criteria: (1) a shared organizational field (Scott 1995, 56) of transportation; (2) shared geography and demographics of the region of Los Angeles County; and (3) shared responsibility for several billion dollars in capital project costs. These criteria permit a focus on the specifics of institutional development and address such variables as field, location, and costs. The limits of these criteria caution against generalizing the findings beyond the field of transportation or the metropolitan region of Los Angeles County.

A case study approach is favored when seeking to explain the how and why of an issue (Yin 1994, 9), as well as when exploring institutional process questions (Scott 1995, 146). The focus on three organizations permits a comparison among different cases and analysis that builds on shared findings. After a brief introduction of each case, the subsequent presentation is organized around key themes rather than the chronology of each case. This approach allows comparisons and contrasts across major findings.

For this research, four primary sources of information were used: (1) interviews with key decision makers who were elected officials, board members, and agency executives; (2) public documents from federal, state, and local agencies; (3) journal articles and books researching the specifics of the Los Angeles region, particularly transportation; and (4) contemporary newspaper articles.

The interviews with participants focused on their perceptions of seminal events and mechanisms. The limitations of individual perceptions and recollections of events call for the use of additional sources of information and introduce the risk of selection basis in choosing interviewees. However, the narratives provided by those interviewed provide an opportunity to "explore specific phenomena, such as leadership and organizational change" (Ospina and Dodge 2005, 143). The use of multiple sources addresses Yin's $(1994,92)$ suggestion on the comparative advantage of using multiple sources of information to develop "converging lines of inquiry."

\section{The Three Cases: An Overview}

The Los Angeles County Transportation Commission (LACTC) offers a case study in politics designing conflict into the structure of an agency from the start. The creation of the LACTC in 1976 was seen as partly the result of repeated failures by the Southern California Rapid Transportation District (RTD) to secure new-start rail construction funding for a rail system from the federal government. The legislative enactment of the LACTC 
was intended, in the words of legislative staff member D. J. Smith (2000), to allow the LACTC to "wrestle control" of transportation policy making from two existing regional agencies: the RTD and the Southern California Association of Governments. The LACTC became responsible for receiving 1978 Proposition A funds, a measure that created a local half-cent sales tax to finance regional rail construction, providing a share to the RTD for subway construction and bus operations and allocating much of the remaining funds for construction of LACTC's light rail lines.

This arrangement left the region with two parallel transportation agencies, the RTD and LACTC, each in charge of massive public works construction projects. Both relied on a mixture of federal, state, and local funds, and both had nearly identical elected officials appointing their representatives to serve on their boards of directors, though the agencies diverged wildly in their policy choices, as noted by longtime board member Marvin Holen (1997) and former LACTC executive director Neil Peterson (2000). Starting in the mid-1980s, a series of efforts began to consolidate the agencies.

The second case study begins in 1992, when the RTD and LACTC were merged though legislation sponsored by Los Angeles-area state senator Richard Katz. As a result, the largest public works project in the United States became the responsibility of a newly created agency, the Metropolitan Transit Agency (MTA). The MTA is a case study in the breakdown of the promise to build all the lines drawn on the napkin in the New Otani hotel and promised to the 8 million residents of Los Angeles County.

According to Katz (2000), the goals of the merger were to improve accountability and to reduce conflict between agencies in order to improve transit agency performance in Los Angeles, both in bus operations and rail construction. However, by 1998, the MTA had exhausted the available funding, precluding the construction of future lines. As prominent California historian Kevin Starr has noted, the funding looked like "Ponzi schemes the MTA had financed itself" $(2004,556)$. According to an analysis conducted by the former controller of the RTD, "Every MTA rail project has had significant cost overruns, with some final costs running as high as four to six times the original planning estimates" (Rubin, Moore, and Lee 1999, 198).

The recurrence of challenges in accountability led the legislative sponsor of the consolidated MTA to suggest-less than a decade later-that the new agency be broken up (Katz 2000). Similarly, the California Transportation Commission suggested in its 1998 annual report, "The root of the problem may lie in the MTA's governing structure, which combines the function of a regional planning and funding agency with the function of a transit operating and construction agency" (1999, I-149).

The third agency, The Alameda Corridor Transportation Authority (ACTA), offers a study in board members seeking political control of expenditures. The evolution of the agency reflects a movement toward political control in order to reduce the uncertainty of local politics in financing rail construction. The Alameda Corridor project evolved from an advisory committee formed in 1980 by the Southern California Association of Governments that studied the movement of cargo from the harbors of Los Angeles and Long Beach. The advisory committee's report led to funding for highway improvements and additional study of options for improving the freight-rail line transporting cargo from the Ports of Long Beach and Los Angeles to downtown and nearby rail yards.

After a feasibility study was conducted, the ACTA was created as a new authority to complete the design, capture the needed funding, and build the project. A joint powers agreement between the Port of Los Angeles, the Port of Long Beach, and the six municipalities that the proposed rail-cargo line would run through created the Alameda Corridor project. The ACTA's governing structure evolved significantly over the course of the project, eventually revoking representation from any municipal jurisdiction that did not contribute financially to the construction. The ACTA's governance structure evolved in response to the need to use public and private sector funding and debt issuance to create a structure that could credibly deliver the promised project on time and on budget.

\section{An Institutional Framework for Case Analysis: Politics and Cooperation}

The state and local elected officials who designed each of the three agencies - the LACTC, MTA, and ACTA - were well versed in politics. The politics included choices about representation on the governing boards, the agencies' respective missions, and the authority provided to each agency. The evolution of each agency reveals the impact of politics.

The impact of political considerations on the design of new public agencies is central to the framework that Terry Moe calls the politics of structural choice. Moe starts with the premise that public agencies are not designed to be efficient: "Because American politics is unavoidably a process of compromise, then, public agencies will tend to be structured in part by their enemies - who want them to fail" (1990a, 230). The fundamental difference of this approach from other institutional approaches is that the failure of public organizations is not incidental but deliber- 
ate-it is the product of politically rational calculations (Schlager and Blomquist 1996). As institutional scholar Richard Scott has noted, these organizational designs are "rationally constructed edifices established by individuals seeking to promote or protect their interests" $(1995,27)$. For rational reasons, an agency might not be designed to serve the public interest in complex settings of uncertainty, incomplete information, and opportunism (Zegart 1996). New agencies have features that emerge from the interplay of interest groups involved in the negotiations over design (Moe 1990b, 143).

Moe's framework seeks parsimony to explain the design of public agencies through a few key features. The five predominant features of politics-sustaining competition can be summarized as follows: (1) majority rule is inherently unstable, making durable agreements very difficult and opportunism potentially strong (Shepsle and Weingast 1995); (2) the precarious nature of majority rule creates incentives for the current majority to insulate newly formed agencies from subsequent politics, limiting their responsiveness to future majorities (McCubbins, Noll, and Weingast 1989, 443); (3) the need for compromise in American democracy typically necessitates support from opponents, structuring interest group conflict into an agency without procedures for resolving disagreements; (4) the coercive nature of public authority causes citizens and opponents of newly formed agencies to protect themselves from the exercise of this power (Moe 1991, 123), a long-standing challenge of democracy (Miller 2000, 289); and (5) long-term political uncertainty places a premium on trying to anticipate future contingencies prior to available information (Shepsle and Weingast 1995, 23).

Suggestions about mechanisms for cooperation in the context of multiple and equal participants, as exists in the fragmentation of authority in the Los Angeles cases, can be found in the research literature on selfgovernance of common-pool resources. In explaining the conditions needed to create and sustain voluntary cooperation, this research examines the evolution of rules, the processes for structuring those rules, the mechanisms for enforcing agreed-upon rules, and the sanctions for infractions (Blomquist 1992, xiii). Moreover, the institutional analysis in this tradition is particularly sensitive to context and the patterns of interactions in complex relationships (Carlsson 2000).

The framework of common-pool resources research is not typically applied to the production of public goods, such as rail transit, because those goods are not seen as possessing the required attributes of exclusion and subtractability (Tang 1992, 4). However, shifting the unit of analysis from individual users to competing political jurisdictions that want to share in a common funding resource-in this case, a countywide dedicated sales tax - provides a case that is analogous to the common-pool resource problem. Overproduction by one or several municipalities could leave no transit resources for other municipalities.

The focus on resource-allocation decisions in commonpool resource research helps explain the evolution of mechanisms that sustain cooperation (Ostrom 1990). The five predominant features of self-organized cooperation can be summarized as follows: (1) adaptation, whereby agencies rely on local autonomy to craft solutions, with significant participation from all appropriators; (2) credible commitment, with an expectation among participants that any commitment to future allocations will be honored; (3) conflict resolution, with grievance processes that respond to allocation, equity, enforcement, and other concerns among all those sharing the resource; (4) credible enforcement, which prevents overappropriation by any one user or group of users and the depletion of shared resources; and (5) effective monitoring of the resources with an agreed-upon, neutral source of reliable information.

A rich set of findings has converged to explain political institutions. Politics of structural choice theory takes these and finds a variant of the Hobbesian world of politics: "nasty" and "brutish" but not short. Likewise, well-developed research on social dilemmas can be seen as suggesting "a world of possibilities rather than necessity" (Ostrom 1998, 16). The connection of the two sets of findings better explains both sides of the same coin of collective action problems: the demand side of Hobbesian failures and the supply side of successes without the intervention of a Leviathan. The application of these two frameworks anticipates what otherwise appears to be a random set of events.

\section{Hypotheses: Testing a Framework of Governance}

Four hypotheses provide empirical tests to determine whether the performance limitations found in the politics of structural choice research can be overcome by the cooperative mechanisms found in commonpool resource research.

$\mathbf{H}_{1}$ : Sustained project control depends on mechanisms to solve the instability of majority rule by providing for local adaptation.

$\mathbf{H}_{2}$ : Accountability derives from reducing agency insulation from politics while providing mechanisms for credible commitment.

$\mathbf{H}_{3}$ : Conflict is built into regional agencies by political design.

$\mathbf{H}_{4}$ : Agency authority needs coercive power in order to increase resources while developing 
agreed-upon sanctions to prevent

overappropriation.

\section{Application of the Hypotheses to the Cases}

Sustained project control depends on mechanisms to solve the instability of majority rule by providing for local adaptation (hypothesis 1). In the first case study, the LACTC's passage of the countywide sales tax addressed the instability of majority rule. The seminal event early in the agency's existence, the sales tax measure, did not have a sunset clause, making it unique in the state of California. The LACTC's success in passing the measure, particularly when contrasted with repeated failures by its predecessor agency, legally provided sustained project control over both the light rail and heavy rail projects by generating a local revenue source. In addition to the absence of a sunset clause, a second notable feature of the Proposition A measure stands out: It addressed specific local conditions. Bus riders received a transit fare subsidy. Rail construction received a guaranteed funding stream. Each of the more than 60 municipalities in the county received a "local return" portion for transit-related projects, broadly defined. The revenue from the LACTC's Proposition A sales tax ballot measure was adapted to very specific local conditions.

The second case study illustrates how an agency-the MTA, which inherited the Proposition A fundingfound a solution to the problem of the instability of majority rule. The challenge that the MTA faced in sustaining control of rail construction funding derived partly from the expectations encouraged by the promises of Proposition A. The promise of new rail transit lines that would be accessible to neighborhoods throughout Los Angeles County was difficult to fulfill. The decade between the passage of Proposition A in 1978 and the merger of the LACTC and RTD to form the MTA saw the near completion of only two light rail lines and one segment of the downtown subway. These projects represented only a small portion of the proposed routes presented to voters in 1978 on the Proposition A ballot map.

Moreover, after the expiration of the fare subsidies, the MTA, as the successor to the RTD, needed to address the expectations of bus riders served by the MTA. Though not formally the result of a vote, the success of the bus riders in pressing for the consent decree to set aside funding for higher levels of bus service can be seen as an extension of the majority rule process, through which powerful constituencies can overturn previously agreed-upon deals.

The third case study provides an enduring and stark solution to the vicissitudes of the democratic process. The major funders of the ACTA - the Ports of Los Angeles and Long Beach-gained control of the governing body and prevailed in court. Removing the six mid-corridor city representatives from the joint powers authority solved the threat of instability posed by majority rule by eliminating the municipal coalition that opposed the cities of Los Angeles and Long Beach and their port representatives. However, while insulating the joint powers authority from the instability of majority rule, the ACTA still provided for local adaptation. Specifically, the authority negotiated two types of detailed, legal agreements with each of the mid-corridor cities: (1) a memorandum of understanding for specific transportation-related improvements in each jurisdiction at a specific funding level, and (2) a memorandum of understanding that assured timely construction permitting by each municipality. These two types of legally binding memoranda addressed very local needs and expectations of the cities where the rail trench would be located.

Accountability derives from reducing agency insulation from politics while providing mechanisms for credible commitment (hypothesis 2). The quest for accountability can be seen in the evolution of the legislation that created both the LACTC and MTA. Though enacted more than a decade apart, both bills initially had language requiring elected officials, appointed as principals, to attend board meetings, allowing for no alternates.

The case of the LACTC illustrates the impact of the absence of mechanisms for accountability. Noticeably absent in the construction of Proposition A were features to ensure that the promised rail projects would be built. Longtime RTD board member and former chairman Marvin Holen (1997) notes that in addition to pressing the RTD for accountability in its spending on the downtown subway and bus operations, the LACTC's 30-year plan further extended the time horizon and leveraged funding sources, but it did not address the fundamental difficulty of allocating resources among competing claims. In many ways, Proposition A and the LACTC's plan mirrored the approach that William Blomquist's (1992) extensive study of Los Angeles region water basins terms the "California solution." Blomquist found a repeated set of choices to create more common-pool resources, injecting river water into water basins rather than battling the overallocation of existing resources. For the LACTC, the California solution succeeded to the extent that the LACTC avoided accountability mechanisms for ensuring that all promises for rail construction could be met.

The LACTC also did not succeed at insulating the agency from future legislative changes. Rather, a major impetus for the abolition of the LACTC resulted from legislative concern over its lack of accountability. The success of the California solution, with promises of resources to competing expropriators, came at the price of credible commitment. Ultimately, the cost of 
the missing accountability mechanisms was the existence of the agency itself. The merger of the LACTC and the RTD was driven by a search for better ways of ensuring public accountability for spending public funds.

The cost of accountability was a bill that was ultimately paid by the successor agency, the MTA. The agency had difficulty sustaining the promises of the LACTC's 30-year

plan and scaled back the time frame for construction and deliverables in an attempt to address the expectation of increased accountability. The hiring of a fourth director, Julian Burke, in the third year of the agency's existence was the result of ongoing problems in resource allocation. In assuming the helm of the MTA, Burke (2001) stated that he recognized agency credibility as the key problem. According to Burke, the imposition of a moratorium on new rail construction sought to resolve the impossibility of satisfying the four concurrent commitments of the MTA to fund separate rail construction projects as its first priority. The halt on commitments to new rail construction became a mechanism for restoring credible commitment with federal and state funding agencies. In addition, the moratorium stressed the priority of ensuring the agency's accountability.

The case study of the ACTA shows a preoccupation with accountability in the formation of the agency as a joint powers authority. The joint powers authority form of governance limited participation to jurisdictions that were directly affected by the rail construction. Moreover, the agency eventually excluded six municipal jurisdictions with construction traversing their downtowns. Unlike the other two case studies, the ACTA evolved mechanisms giving Long Beach and Los Angeles city and port representatives sole authority to approve appropriations.

For the ACTA, accountability emerged as a dominant theme because of its innovative financing mechanisms, which were dependent on the sale of bonds. Investors expected a project with strict financial and construction accountability. In order to guarantee a sufficient revenue stream to service the debt, the ACTA connected the demand side for construction to the supply side of funding. The ACTA required majority approval by the jurisdictions that were responsible for repayment of the debt; this created strong incentives to contain costs (the demand side) and to realistically project future revenue streams (the supply side). The ability to sell the required bonds reflected the ACTA's success in developing mechanisms for accountability through the voting structure, agreeing on detailed memoranda of understanding with affected cities, and using design and build project contracts. These mechanisms provided accountability that translated into successful funding.

Conflict is built into regional agencies by political design (hypothesis 3). Conflict emerges as a dominant feature in each of the case studies. The interest groups

vary in each of the cases, but conflict is ever-present. From the onset, each agency had significant conflict structured into it. Rather than resolving preexisting conflicts, the formation of these new agencies initially confronted increasing levels of conflict among competing interests. The legislative sponsor, Richard Katz (2000), and staff member Caprice Young (2001) both noted that the level of conflict in one of the new agencies - the MTA — ran much deeper than ever imagined. The evolution of mechanisms to resolve conflict varied among the agencies. The cases illustrate the results of unchecked conflict and the utility of mechanisms to resolve conflict.

The LACTC was literally created to wrest control of planning and building rail lines from the existing agencies. The minimal conflict that arose in choosing the initially constructed Blue Line resulted from the alignment of three one-time features: (1) the initial availability of an abundance of funds from Proposition A and initial low-cost construction estimates; (2) an apparent consensus on the logic of connecting the two largest urban areas of the county, downtown Los Angeles and Long Beach (Richmond 2000); and (3) the political clout of those supporting the line selection. However, the success of Proposition A at initially avoiding conflict through the promise of resources for everyone also deferred the need to develop mechanisms for resolving grievances. Again, the success of the California solution for the LACTC also contained the elements of the agency's eventual downfall.

Noticeably absent in the LACTC were mechanisms to resolve two virulent types of conflict: demographic 
and interagency conflict. Because of the Proposition A map, residents in various regions of the county had different expectations of the new rail lines. The realities of the line-selection process, construction costs, and staffing requirements made the construction of all the promised lines impossible. Former undersecretary of the U.S. Department of Transportation, Mortimer Downey (2001), noted at the time that overexpenditures were not atypical for new-start rail construction throughout the country (GAO 1998).

As the successor agency, the MTA had no mechanisms in place to anticipate or successfully resolve conflict.

The merger of the two agencies was seen as one means of resolving their differences. The most noticeable evidence of the failure of mechanisms for allocation decisions led to bus rider discontent, a long-standing RTD concern, according to board member Marvin Holen (1997) and former executive staff member Ralph De La Cruz (2001). Competition both within and outside the agency between advocates of rail construction funding and advocates of bus operations funding prevented the establishment of a procedure for resolving their differences. Rather, the courtsupervised consent decree requiring levels of bus funding emerged in the absence of any MTA-managed process.

In the ACTA case, the governance model initially included conflict among those paying for the project, the Ports of Los Angeles and Long Beach, and the six mid-corridor cities through which the rail lines would be built. Only after the cities of Los Angeles and Long Beach prevailed in a court battle to remove the other six cites and detailed agreements were reached on improvement funding in each excluded city did the conflict end.

Agency authority needs coercive power to increase resources while developing agreed-upon sanctions to prevent overappropriation (hypothesis 4 ). The problem of spending more than was appropriated became paramount. Matching the projected revenue stream to the projects for each agency challenged the leadership in all three cases. The concept of sanctions from common-pool resource management research helps explain how this problem was overcome. The three cases illustrate the evolution of varied approaches to a similar problem.

The LACTC case study demonstrates the limits of promising increased appropriations to meet each of the competing needs. The LACTC's evolution is notable for its absence of mechanisms to prevent overappropriation of resources. Through Proposition A, the agency succeeded in gaining coercive public authority - in this case, sales tax authority - to increase appropriations. In creating the new resource, the LACTC did not develop mechanisms to prevent early expropriators from exceeding initially agreedupon limits. The escalating cost of the initial LACTC rail line from downtown Los Angeles to Long Beach not only resulted from additional construction items but also the absence of any agreed-upon sanctions for expropriators. Rather than reduce financial commitments, the executive director, Neil Peterson (2001), used the 30-year plan to deliberately leverage additional funding though bond financing, borrowing against future sales tax revenues. In the absence of local mechanisms to prevent the initial projects from exhausting the common resource of sales tax revenues, legislation was passed to set aside funding for the San Fernando Valley.

The case of the MTA illustrates the results of deferring sanctions for expropriators. All new projects were placed on hold. This action addressed future construction but did not lead to sanctions against the beneficiaries of overappropriations. But the moratorium did begin a process that connected allocations to available current resources.

However, the limits of the moratorium in preventing excess appropriations can be seen in the movement by civic leaders of the area north of downtown to create their own authority, with a specific percentage of sales tax revenue allocated to extend the construction of the Blue Line to Pasadena. Also, the passage of a countywide proposition in 1998 to prohibit expenditures on construction extending the newly completed 18-mile subway can be seen as compensation for past overappropriations, though at the expense of promised projects.

The case of the Alameda Corridor demonstrates the successful linkage of appropriations and sanctions. The seminal event of the ACTA case-the forcible removal of the six mid-corridor cities - directly addressed the problem of overcommitment of resources by parties that were not contributing resources. The ACTA case demonstrates the evolution of mechanisms that gave the appropriators, the ports and cities of Los Angeles and Long Beach, direct control over the appropriations. Removing the mid-corridor cities removed votes for appropriations that would not be paid for by those cities.

ACTA's dependence on funding through bonds backed only by the proceeds of future revenues effectively guarded against the overcommitment of appropriations. Potential investors would have been scared away by expenditures exceeding realistic projections of revenue from freight charges for corridor use over the next 30 years. This investor flight would have necessitated higher interest rates in order to attract investment, in turn increasing repayment costs and driving lifetime project costs even further beyond the reach of revenue projections. Without limiting appropriations, 
this upward spiral would have resulted in either a lack of funds to start construction or a need for funding from other agencies and a loss of project control by the ports and cities of Los Angeles and Long Beach. Project control and construction through bond financing linked the demand side of politics to the supply side of resource allocation. The success of the ACTA resulted from connecting both sides of the equation.

\section{Findings}

Four major findings emerge from these case studies:

1. Terry Moe's theory is supported in one respect: Interest group politics lead to agency design that structures conflict into the organizations. The cases show that conflict is inevitable-not the accidental by-product of insufficient deliberation or the absence of intelligent foresight.

2. One aspect of Terry Moe's theory is not supported: Out of the Hobbesian world of the politics of structural choice, public agencies are not inevitable failures. Though affected by conflict and the other baggage of political design, public agencies can nonetheless evolve nested institutional solutions that concurrently address political design problems. 3. Successful regional solutions are intensely local. 4. The California solution of solving allocation dilemmas by importing more resources was a strategy employed to solve design problems in two of the three agencies studied.

The first finding is that conflict was a predictable feature in each of these cases. The creation of the LACTC intentionally placed the new agency in conflict with the existing transit agency, the RTD, and the existing regional planning agency, Southern California Association of Governments. The MTA intended to resolve conflict by merging the LACTC and RTD, but it became mired in internal conflict between two radically different organizational cultures and external conflict with funding agencies, areas competing for new lines, and bus riders. The case study of ACTA provides a vivid illustration of bitter conflict between competing political jurisdictions: the port cities of Los Angeles and Long Beach versus the six mid-corridor cities. The ACTA case illustrates the success of the supply-side California solution in solving the demand-side problems of conflict, as well as the success of new mechanisms specific to local needs.

Each agency developed different mechanisms to address the conflict inherent in its design. The LACTC developed Proposition A to provide resources to competing interest groups: fare subsidies for bus riders, transportation funding for local municipalities, rail lines to every region in the Los Angeles County for commuters, and a subway in downtown Los Angeles for the business community. The MTA executive director imposed a moratorium on new-start construction to abate internal conflicts between rail builders and planners in the new agency and transit operators, as well as external differences among the various regions that wanted new rail starts, the bus riders who wanted better bus service, and engineering and construction firms that wanted more contracts. Then-executive director Gill Hicks (2001) described a process in which the ACTA eventually had to remove the mid-corridor cities as voting members of the authority in order to proceed.

The second finding that connects the cases is that solutions were not linear in addressing one problem after another sequentially. Rather, the mechanisms evolved and responded simultaneously to several conditions needed for cooperation, providing nested solutions to problems. In the LACTC case, the development of Proposition A addressed problems of conflict by allocating resources to all competing constituencies, by responding to the problems of control by not having a sunset provision typical of other sales tax measures, and by acquiring authority through local taxing powers.

The action of the executive director of the MTA in imposing a new construction moratorium simultaneously responded to the conditions of accountability and uncertainty while buying time to respond to paralyzing internal and external conflicts. In the third case study, the ACTA's detailed memoranda of understanding with the mid-corridor cities addressed the problems of conflict through the California solution of directing new resources to competing interests.

The third finding related to each case involves local adaptation mechanisms. Each case study exhibits specific solutions that were unique to the context of the newly created public agency. In addition, each agency developed mechanisms specific to the region and different from similar agencies in the state of California. In some cases, the mechanisms were novel to transportation agencies in the United States. The LACTC's sales tax proposition lacked a sunset provision, unlike any other agency in the state. The MTA's moratorium was described by former executive director John Dyer (2001) as a nationally unique step, as was the federal funding concept of minimal operating segments inherited from the RTD. The third case study of the ACTA demonstrates several solutions that were specific to the Alameda Corridor project, including the use of design and build construction contracts in the region. Also, the ACTA's employment of user fees and container fees leveraged federal funding and guarantees needed for private investment in bonds (Agarwal, Giuliano, and Redfearn 2004, 12).

The fourth finding from each case is the connection of demand-side politics and supply-side cooperation to 
augment resources. The LACTC provided transportation funds to each of the municipalities in the county, fare subsidies to bus riders, and promises of rail lines to nearly every neighborhood. The ACTA funded sought-after projects in each of the mid-corridor cities, provided jobs to local residents, offered contract opportunities to local businesses, and mitigated contaminated soil and water along the corridor. Credibility emerged as an important consideration, not simply in an abstract sense but in the ways decision makers personally related to each other. Long-standing personal relationships characterized the interaction of leading decision makers. In the LACTC, the first executive director, Jerry Premo, who had previously worked at the U.S.

Department of Transportation, was perceived as having credibility with funding agencies at both the federal and state levels. The credibility of Julian Burke with the undersecretary of the U.S. Department of Transportation, Mort Downey, was an important element in the MTA's moratorium, as Burke emphasized fiscal credibility with all funding partners and the MTA's board of directors. In the third case study of the ACTA, the long-standing professional credibility of the initial project director, Gill Hicks, and the SCAG Director, Mark Pisano, with federal, state, and local partners contributed significantly to the emergence of cooperation.

\section{Implications of the Research}

The untold story of the three public agencies studied shows that conflict is endemic and that mechanisms for cooperation are contextual. In short, history and local circumstances provide both the sources of the conflict that is inherent in politics and the sources of the solutions that can evolve in order for cooperation to emerge. The findings in these cases suggest that regional governance is not a flight from politics but an evolution of mechanisms that respond to competing interests. What determines the success or failure of governance is not the presence of interest group conflict but rather the mechanisms for cooperation that evolve in the presence of that conflict.

A second implication is that the three cases empirically support the application of the combined theories. The theories anticipate the types of problems that dominate agency actions. The application of the combined theories helps to explain how problems of regional cooperation in a political environment are solved or not solved in terms of the five proposed features. Rather than producing an overwhelming set of particulars, the combination of two distinct research traditions - the politics of structural choice and common-pool resource management-reduces the set of variables that explain the governance performance of each agency. The varied sets of results found in these case studies are anticipated and explained by a framework that synthesizes the major features found in the politics of structural choice and common-pool resource research findings. This combined framework identifies the explanatory variables and provides a more robust framework for understanding the outcome variables.

A third implication is that a focus on mechanisms moves well beyond the study of organizational or governance structures, suggesting that the structural emphasis on consolidations by metropolitan government advocates is an illusory solution. The consolidation of agencies in the MTA case study does not show that consolidation solves preexisting conflict. Conflict continued at the staff level and with outside contractors, undermining the public's perception of the agency. The level of animosity between the two agencies was not accounted for in the legislation that created the MTA. The complex politics of the region worked against solutions that did not provide resources to each of the competing interest groups and subregions. Consequently, consolidation into a new organizational structure was insufficient to resolve conflict.

This combined framework helps to explain why savvy, seasoned public managers with significant political acumen, such as John Dyer and Neil Peterson, are eventually overtaken by the politics of the region. The combined research framework also explains why new executive directors and consolidated organizations do not necessarily produce better cooperation. More than taxonomy, the synthesized framework anticipates the leadership challenges that must be addressed in a political environment in order for cooperation to emerge across political jurisdictions. The findings here suggest that the leadership challenges of executive directors in newly designed public agencies require not only interpersonal and organizational-level leadership skills but also the ability to negotiate at the institutional level. The agencies' success at securing local and federal funding for each of the projects reflects both horizontal and vertical leadership skill sets_critical for negotiating among competing jurisdictions, on one hand, and among the public, regional agencies, the state, and the federal government, on the other hand. In addition, the ACTA case suggests the need for intersectoral skills to leverage public monies in order to attract private sector capital. 


\section{Future Research}

The use of institutional analysis in the three case studies shows the potential of expanding the concepts and terminology developed in the research on public agency design to explain the impact of political design on new governance approaches. The case studies also show the potential of applying the research on the evolution of mechanisms for cooperation to regional governance challenges. Although not always found in the study of governance, the mechanisms that evolved are key to explaining what occurred in these cases.

Future research should apply the four conditions found in these three case studies in a larger empirical test. Research needs to move beyond one region and one field to test the hypotheses in different geographic locations, different policy domains, and smaller agencies, as well as large-scale agencies. The suggestion of a "California solution"-adding more resources to solve the demand-side competition of politics in governanceshould be researched in other geographic regions, testing supply-side solutions in promoting cooperation across competing local jurisdictions. Also, the data collection could be expanded to include more comprehensive surveys of key decision makers.

Additional research could be done by testing the four conditions for cooperation across a variety of singlepurpose and multipurpose regional governance agencies and councils of governments, as well as newly designed federal agencies.

Future research also could focus on public managers in these politically charged environments-specifically, how they navigate and negotiate newly and deliberately designed institutional constraints. Questions about the leadership skills needed in these environments provide a new way of framing leadership research, moving beyond endless contingency theory, with its countless maps and categories of leadership skills needed in the public sector.

\section{Conclusion}

The three cases offer a rich portrait of the dynamic features of American politics and the evolution of mechanisms for cooperation. The forces that were present when each agency was created continued to shape their evolution. Their initial design, however, was not their destiny. For each agency, seminal events shaped the evolution of the multibillion-dollar projects they were charged with building. The success of the LACTC in Proposition A became a source of expectations that were not met. The MTA faced a level of expectation that had to be reshaped through a moratorium. The ACTA's evolution solved the varied conditions needed for effective cooperation

through a variety of mechanisms. Varied new mechanisms were developed for each project.

The framework applied in the study of these cases effectively anticipated the types of problems each agency had to overcome. In effect, the framework anticipated the limits of political design and the potential for cooperation to evolve through the development of certain features. The utility of these theories in anticipating the wide range of successes and failures proved an exciting feature of the research. Rather than a collection of inexplicable events, the framework provided a useful focus on variables that could explain the emergence of cooperation in a political environment. Rather than random occurrences, the actions of each of the agencies responded to the limits that the politics of design placed on them. The evolution of cooperative mechanisms that solved the problems of politics explained an important part of the performance of each agency.

When drawing future rail lines on a cocktail napkin at dinner in downtown Los Angeles in 1978, the participants could not have anticipated the governance challenges that would unfold over the next two decades. But their bold invitation to build a regional rail system initiated an opportunity to develop regional governance mechanisms to address the realities of politics. The three cases illustrate the complexities of politics and the challenges of cooperation in political contexts. The evolution of the cases shows the importance of the local context and the possibility of the evolution of unique adaptations. The presence of conflict did not forestall the emergence of varied governance solutions to address the cooperation needed to work across political jurisdictions. The cases suggest that even though public agencies may not be designed to be effective-

politics inevitably entails conflict-cooperation can nonetheless emerge and evolve. The limits of politics are not random or predestined. Likewise, the emergence of sustainable governance is neither random nor preordained.

\section{Acknowledgments}

The forces that were present when each agency was created continued to shape their evolution. Their initial design, how-

ever, was not their destiny.
Thank you to Yan Tang, Ross Clayton, and Kevin Starr for their suggestions and review, and to the three anonymous reviewers.

\section{References}

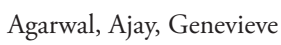

Giuliano, and Christian

Redfearn. 2004. The Alameda Corridor: A White

Paper. Los Angeles: Metrans Transportation

Center/USC Keston Institute for Infrastructure. www.metrans.org/pdfs/AlamedaCorridorWhite Paper.pdf [accessed January 30, 2007]. 
Blomquist, William A. 1992. Dividing the Waters: Governing Groundwater in Southern California. San Francisco: ICS Press.

Burke, Julian. 2001. Interview with the author, June 26, Los Angeles.

California Transportation Commission. 1999. Annual Report for the Year of 1998. Sacramento: California Transportation Commission.

Carlsson, Lars. 2000. Policy Networks as Collective Action. Policy Studies Journal 28(3): 502-20.

Clingermayer, James C., and Richard C. Feiock. 2001. Institutional Constraints and Policy Choice: An Exploration of Local Governance. Albany: State University of New York Press.

De la Cruz, Ralph. 2001. Interview with the author, January 10, Los Angeles.

Downey, Mortimer. 2001. Interview with the author, March 13, Newark, NJ.

Dyer, John. 2001. Interview with the author, May 17, Los Angeles.

Edelman, Edmund D. 2001. Interview with the author, February 5, Santa Monica, CA.

Feiock, Richard C. 2004. Introduction: Regionalism and Institutional Collective Action. In Metropolitan Governance: Conflict, Competition, and Cooperation, edited by Richard C. Feiock, 3-17. Washington, DC: Georgetown University Press.

Heinrich, Carolyn J., Carolyn J. Hill, and Laurence E. Lynn, Jr. 2004. Governance as an Organizing Theme for Empirical Research. In The Art of Governance: Analyzing Management and Administration, edited by Patricia W. Ingraham and Laurence E. Lynn, Jr., 3-19. Washington, DC: Georgetown University Press.

Hicks, Gill. 2001. Interview with the author, June 25, Pacific Palisades, CA.

Hill, Carolyn J., and Laurence E. Lynn, Jr. 2005. Is Hierarchical Governance in Decline? Evidence from Empirical Research. Journal of Public Administration Research and Theory 15(2): 173-95.

Holen, Marvin. 1997. Interview with the author, Los Angeles.

Katz, Richard. 2000. Interview with the author, September 28, Sacramento, CA.

March, James G. 1997. Administrative Practice, Organizational Theory, and Political Philosophy: Ruminations on the Reflections of John M. Gaus. PS: Policy Science and Politics 30(4): 689-99.

McCubbins, Mathew D., Roger G. Noll, and Barry R. Weingast. 1989. Structure and Process, Politics and Policy: Administrative Arrangements and the Political Control of Agencies. Virginia Law Review 75(2): 431-82.

Miller, Gary. 2000. Above Politics: Credible Commitment and Efficiency in the Design of Public Agencies. Journal of Public Administration Research and Theory 10(2): 289-327.
Moe, Terry M. 1990a. Political Institutions: The Neglected Side of the Story. Special issue, Journal of Law, Economics, and Organizations 6: 213-53.

- 1990b. The Politics of Structural Choice:

Toward a Theory of Public Bureaucracy. In Organizational Theory: From Chester Barnard tothe Present and Beyond, edited by Oliver Williamson, 116-53. New York: Oxford University Press. - 1991. Politics and the Theory of

Organization. Special issue, Journal of Law, Economics, and Organization 7: 106-29.

_ 1994. Integrating Politics and Organizations: Positive Theory and Public Administration. Journal of Public Administration Research and Theory 4(1): 17-25.

Ospina, Sonia M., and Jennifer Dodge. 2005. It's About Time: Catching Method Up to MeaningThe Usefulness of Narrative Inquiry in Public Administration Research. Public Administration Review 65(2): 143-57.

Ostrom, Elinor. 1990. Governing the Commons: The Evolution for Collective Action. Cambridge: Cambridge University Press. 1998. The Comparative Study of Public

Economies. American Economist 42(1): 3-17.

Peterson, Neil. 2001. Interview with the author, February 1, Los Angeles.

Pisano, Mark. 2001. Interview with the author, February 5, Los Angeles.

Remy, Ray. 1998. Interview with the author, October 20, Sacramento, CA.

Richmond, Rick. 2000. Interview with the author, December 4, Irwindale, CA.

Rubin, Thomas A., James E. Moore, and Shin Lee. 1999. Ten Myths about U.S. Urban Rail Systems. Transport Policy 6(1): 57-73.

Schlager, Edella, and William Blomquist. 1996. A Comparison of Three Emerging Theories of the Policy Process. Political Research Quarterly 49(3): 651-72.

Scott, W. Richard. 1995. Institutions and Organizations. Thousand Oaks, CA: Sage Publications.

Shepsle, Kenneth A., 1986. Institutional Equilibrium and Equilibrium Institutions. In Political Science: The Science of Politics, edited by Herbert F. Weisberg, 51-81. New York: Agathon Press.

Shepsle, Kenneth A., and Barry R. Weingast. 1995. Positive Theories of Congressional Institutions. In Positive Theories of Congressional Institutions, edited by Kenneth A. Shepsle and Barry R. Weingast, 5-35. Ann Arbor: University Michigan Press.

Smith, D. J. 2000. Interview with the author, December 18, Sacramento, CA.

Starr, Kevin. 2004. Coast of Dreams: California on the Edge, 1990-2003. New York: Alfred A. Knopf.

Tang, Shui Yan. 1992. Institutions and Collective Action: Self-Governance in Irrigation. San Francisco: ICS Press. 
U.S. General Accounting Office. 1998. Surface Infrastructure-Costs, Financing and Schedules For Large-Dollar Transportation Projects. Washington, DC: Government Printing Office. GAO/RCED-98-64. www.gao.gov/archive/1998/ rc98064.pdf [accessed January 30, 2007].

Wilson, James Q. 1994. Reinventing Public Administration. Political Science and Politics. 27(1): 667-73.
Yin, Robert K. 1994. Case Study Research: Designs and Methods. 2nd ed. Thousand Oaks, CA: Sage Publications.

Young, Caprice. 2001. Interview with the author, February 5, Santa Monica, CA.

Zegart, Amy Beth. 1996. In Whose Interest?

The Making of American National

Security Agencies. PhD diss., Stanford

University.

\section{We Invite Your Feedback}

The PAR editorial team is in the process of designing an interactive, web-based accessory to the journal to facilitate dialogue and exchange on the printed content.

In the meantime, we invite thoughtful comments in the form of letters. E-mail to: par.letters@cudenver.edu.

Conventional mail: Public Administration Review, GSPA, University of Colorado at Denver and Health Sciences Center, 1380 Lawrence Street, Suite 500, Denver, CO 80204.

Selected letters will be reproduced in future issues! 